\title{
Management Behaviour in Vietnamese Commercial Banks
}

\author{
Thanh Pham Thien Nguyen \\ University of Economics, Ho Chi Minh City \\ Son Hong Nghiem \\ Queensland University of Technology \\ Eduardo Roca \\ Griffith University
}

\begin{abstract}
This study identifies managerial behaviour in Vietnamese banks between the years 2000 and 2014, based on the managerial framework of banks, as identified by Rossi et al. (2009). This framework is built on the interrelationships between efficiency, risk, capital and diversification. This study uses the Z-score to measure insolvency risk, the SFA to estimate cost efficiency, the ratio of total equity to total assets to capture bank capital, and the HHI index to measure the diversification of revenue and earning assets. The results from the 3SLS estimator indicate that revenue diversification has an insignificant impact on insolvency risk, capital ratio and cost efficiency, but earning assets diversification has a negative effect on these three variables, supporting "classical diversification”, “economic capital” and “monitoring” behaviours. Moreover, a decline in cost efficiency leads to a rise in insolvency risk, implying "bad management” behaviour; an increase in risk results in a reduction in cost efficiency, indicating "bad luck" behaviour; and a reduction in capital ratio in the poorly capitalized banks leads to a growth in risk, suggesting "moral hazard” behaviour. The results remain strongly robust when using an alternative risk measurement (the loan loss provision ratio) and an alternative SFA model.
\end{abstract}

Keywords: Vietnam, insolvency risk, capital, efficiency, SFA, three-stage least squares

JEL Classification: G21, G32, C61, C33 


\section{Introduction}

During the last two decades, banks have responded to deregulation and liberalisation by applying technological advances to expand into non-interest activities in order to diversify their earning assets as well as their revenue. There have been several studies investigating the effects of diversification of revenue and earning assets on bank performance, such as those by Chiorazzo et al. (2008), Elsas et al. (2010), Berger et al. (2010), Elyasiani and Wang (2012) and Meslier et al. (2014), and on bank insolvency risk, such as those undertaken by Stiroh (2004), Lepetit et al. (2008) and Sanya and Wolfe (2011). However, the question of whether greater diversification improves bank performance or reduces risk is still a puzzle, as these studies document mixed evidence about the benefits of bank diversification. Moreover, these previous studies investigate the impact of diversification on either performance or insolvency risk using separate linear regressions, which could lead to bias estimates as they ignore the correlation of error terms across equations. The unobserved individual characteristics of banks which affect both diversification and operational performance can cause the error terms across equations to be correlated.

To the best of our knowledge, Rossi et al. (2009) were pioneers in jointly investigating the effects of diversification on bank efficiency, risk and capital for Austrian banks. They used a managerial model which is a system of three simultaneous equations, with efficiency, risk and capital being dependent variables. The managerial model also enables the authors to identify the managerial behaviours of Austrian banks based on the managerial framework proposed by Berger and DeYoung (1997). Berger and DeYoung (1997) used the signs and temporal order between efficiency, risk and capital to identify four types of management behaviour in banks, namely bad luck, bad management, skimping and moral hazard. Meanwhile, Rossi et al. (2009) used the signs of diversification effects on efficiency, risk and capital to characterise five additional behaviours, namely classical diversification, lack of expertise, monitoring, idiosyncratic risk and economic capital.

Based on Rossi et al.'s (2009) research, this study aims to detect the behaviour of management in Vietnamese banks by investigating the interrelationships between cost efficiency, risk and capital and the effects of diversification of revenue and earning assets on these three variables. There have been several studies identifying bank management behaviour based on the framework proposed by Berger and DeYoung (1997), including those 
by Kwan and Eisenbeis (1997) in the United States, Williams (2004), Fiordelisi et al. (2011) and Altunbaş et al. (2001) in the European Union, Deelchand and Padgett (2010) in Japan, Reddy (2011) in India and Tan and Floros (2013) in China. Nonetheless, their findings may not apply to the Vietnamese banking market since it has specific characteristics which differ from those of industrialised and emerging countries.

This study makes three major contributions to the literature. Firstly, this is the first study which applies Rossi et al. (2009)'s managerial framework, which extended the work of Berger and DeYoung (1997) to identify managerial behaviour in banks. Secondly, this is the first study exploring managerial behaviour in Vietnamese banks. Research into management behaviour in Vietnamese banks is important, as Vietnam is one of the leaders in terms of economic performance within the Association of South East Asian Nations (ASEAN) region (Chaponnière et al., 2007; Pomfret, 2013). In order to escape competition pressure from the gradual deregulation and re-regulation process, banks in Vietnam may behave differently from those in other regional countries (e.g., stability or efficiency preference). Thirdly, this study utilises the most updated data set available for Vietnamese banks (2000 to 2014). Finally, this study applies various sensitivity tests to check the robustness of the results (e.g., the use of an alternative risk measurement and an alternative efficiency model and controls unobserved individual heterogeneity). We believe that the lack of a sensitivity test in previous studies could be one of the reasons contributing to the lack of consensus about the effects of diversification on bank performance found in the literature.

The rest of the paper is organised as follows. Section 2 provides an overview of the banking industry in Vietnam. Section 3 presents a review of the literature on the conceptual framework and empirical tests for managerial hypotheses in banks. Section 4 discusses the research methodology and data. Section 5 analyses the empirical results and Section 6 provides a conclusion.

\section{Background of the banking industry in Vietnam}

The Vietnamese system groups credit institutions into state-owned commercial banks, jointstock commercial banks, foreign banks, social policy bank and other credit institutions. Stateowned commercial banks are banks within which over $50 \%$ of the capital is owned by the Vietnamese government, while joint-stock commercial banks are banks within which over $50 \%$ of the capital is owned by private investors, which can be Vietnamese individuals, 
Vietnamese enterprises and foreign investors. Foreign banks are further classified into jointventure banks, foreign bank branches and wholly foreign-owned banks. Foreign banks are banks whose memberships are foreign, while joint-venture commercial banks are partnerships between state-owned commercial banks and foreign banks. At the end of 2014, Vietnam had 93 banks in total, which were comprised of four state-owned commercial banks, 35 joint-stock commercial banks, four joint-venture commercial banks and 50 foreign financial institutions. The social policy bank is a wholly state-owned bank which was established to perform the designated socio-policy lending programs of the government. Other credit institutions include people's credit funds, finance companies and leasing companies.

State-owned commercial banks have lent mainly to state-owned enterprises, while joint-stock commercial banks have primarily served private businesses and households, and foreign banks largely engage in foreign-invested corporates (WorldBank, 2002). In the Vietnamese system of credit institutions, the shares in the deposit market of the social policy bank and non-bank credit institutions are tiny, approximately $0.22 \%$ and $1.21 \%$ in 2006 , respectively, so commercial banks (state-owned, joint-stock and foreign banks) play a crucial role in the banking industry. Table 1 displays the share of deposits by bank ownership types from the year 2000 to 2014. It can be seen that state-owned commercial banks have dominated the deposit market for a large part of the period from 2000 to 2014, although their share gradually decreased over time, while the market share of joint-stock commercial banks reveals a steadily upward trend during the period from 2000 to 2010, but slightly declined after that. Foreign banks account for less than $11.30 \%$ of the deposit market over the period from 2000 to 2014.

Table 1: Share of deposits by commercial bank types

\begin{tabular}{|c|c|c|c|c|c|c|c|c|c|c|c|c|}
\hline Year & 2000 & 2002 & 2004 & 2005 & 2006 & 2007 & 2008 & 2009 & 2010 & 2011 & 2012 & 2014 Overall \\
\hline $\begin{array}{l}\text { State-owned banks } \\
\text { and policy bank }\end{array}$ & 78.40 & 80.50 & 78.10 & 70.80 & 68.67 & 58.07 & 56.06 & 49.71 & 45.29 & 43.92 & 44.78 & $\begin{array}{ll}45.23 \quad 59.96\end{array}$ \\
\hline Joint-stock banks & 11.30 & 10.10 & 13.20 & 15.84 & 22.83 & 33.14 & 35.86 & 42.76 & 45.80 & 45.06 & 43.92 & $43.73 \quad 30.30$ \\
\hline Foreign banks & 10.30 & 9.40 & 9.70 & 9.48 & 8.11 & 8.79 & 8.08 & 7.53 & 8.91 & 11.02 & 11.30 & 11.04 \\
\hline
\end{tabular}

During the last two decades, Vietnam's banking sector has transitioned from a one-tier to a two-tier banking system. Initially, this system was dominated by state-owned commercial 
banks with no foreign participation, but later diversified its market participants to include wholly state-owned banks, partially privatised banks, joint-stock banks, joint-venture banks, wholly foreign-owned banks, foreign banks’ branches and others. Since the 1990s, Vietnam has implemented reforms to deregulate the banking system, for example, gradually opening the banking market to foreign banks and foreign investors, diversifying the ownership in state-owned and joint-stock banks and relaxing constraints on interest rates. Vietnam has also re-regulated the banking system via capitalisation and prudential ratios. This deregulation and re-regulation may have exerted considerable pressure on the management of Vietnamese local commercial banks to improve bank efficiency and stability to survive in an increased competitive market. The dominance of state-owned banks in the Vietnamese banking industry is similar to that in China and India, but the scale of Vietnamese banks are much smaller. Thus, it is of interest to various stakeholders (e.g., policymakers, bank managers and academics) to examine the operational efficiency and behaviours of commercial banks in Vietnam.

\section{Brief literature review}

This section consists of two parts: i) conceptual frameworks to identify managerial hypotheses based on the interrelationships between diversification, cost efficiency, risk and capital; and ii) the empirical studies which have applied these frameworks.

\section{a) Managerial hypotheses}

In 1997, Berger and DeYoung pioneered studies of the conceptual frameworks for the managerial hypotheses of banks. In particular, the authors proposed four hypotheses to explain the dynamic relationship between cost efficiency, risk and capital: bad luck, bad management, skimping and moral hazard. Under the "bad luck” hypothesis, external shocks such as economic downturns and financial crises, precipitate increases in nonperforming loans. To reduce losses, banks have to put more managerial effort into monitoring delinquent borrowers, leading to lower cost efficiency. The "bad management" hypothesis supports the reverse direction of causality - low cost efficiency in the previous period leads to an increase in bank risk in the current period. Bad operational management fails to keep costs under control, resulting in low cost efficiency. Meanwhile, bad risk management (poor credit scoring, loan monitoring and investment analysing) gradually leads to an increase in nonperforming loans. The "skimping" hypothesis states that by skimping resources on monitoring and underwriting loans, banks improve cost efficiency in the short term. 
However, skimping behaviour gradually leads to a deterioration in the quality of earning assets, and hence increases insolvency risk. The "moral hazard" hypothesis predicts that managers in low capitalised banks tend to accept risky portfolios of loans and investments. Moreover, the owners of poorly capitalised banks may be less active in monitoring the management's risk-taking activities. Thus, a decline in capitalisation gradually leads to an increase in risks. With the exception of bad luck, the principal-agent theory in microeconomics can explain these hypotheses because the behaviour of self-interested bank managers may not be in line with the objectives of bank owners. For example, managers can pursue short-term interests to reduce management effort (bad management) or act to maximise short-term profits (skimping and moral hazard), and as a result, receive promotions and bonuses at the expense of the long-term stability and profitability of the owners of the banks.

Berger and DeYoung (1997) proposed using the Granger causality test to identify these four managerial hypotheses (see Table 2). In particular, "bad luck" exists when an increase in risk Granger-causes a decrease in cost efficiency (negative parameter of lag risk in the efficiency regression). The "bad management” hypothesis prevails when a decline in cost efficiency Granger-causes an increase in risk (i.e., negative parameter of lag cost efficiency in the risk regression). “Skimping” behaviour exists when an increase in cost efficiency Granger-causes an increase in risk (i.e., positive parameter of lag cost efficiency in the risk regression). Finally, "moral hazard" behaviour prevails if a decline in capital ratio Granger-causes a growth in risk in poorly capitalised banks (i.e., negative parameter of lag capital in the risk regression).

Rossi et al. (2009) extended Berger and DeYoung's (1997) framework by using the signs of the effect of loan portfolio diversification on risk, efficiency and capital to test for five additional hypotheses, namely classical diversification, lack of expertise, idiosyncratic risk, monitoring, and economic capital. The "classical diversification" hypothesis, which is based on classical finance theory, states that an increase in diversification in the previous period leads to a reduction of risk in the current period. One possible explanation for this hypothesis is the economy of scope in microeconomics theory (i.e., banks diversify their products or services, reducing their $\mathrm{v}$ reliance on traditional lending products and then decreasing the risks of non-performing loans, and hence improving bank stability). This hypothesis implicitly assumes that all other factors, including managerial expertise, remain constant. By 
relaxing this assumption, the "lack of expertise" hypothesis postulates that poor expertise in monitoring gradually leads to an increase in nonperforming loans, reducing bank stability. The "monitoring" hypothesis argues that banks have different monitoring practices for different products. As a result, diversification leads to an increase in monitoring costs, and hence gradually reduces cost efficiency. The implicit assumption about the positive relationship between monitoring efforts and diversification is that bank managers are risk averse. The “idiosyncratic risk" relaxes this implicit assumption and argues that diversification can gradually lead to a reduction of monitoring costs, and hence, improve cost efficiency. This hypothesis is named after a proposal that diversification reduces idiosyncratic risk (i.e., risk that relates to a specific product), hence bank managers can use fewer resources for monitoring. The economy of scope theory in microeconomics may also help to explain this hypothesis (i.e., a bank lowers average costs when multiple products are produced), hence operating costs are reduced within the bank. The economy of scope theory in microeconomics also helps to explain the "economic capital” hypothesis. In particular, as banks improve cost efficiency when diversifying, they gradually require less capital to provide a similar level of services to other banks.

Table 2: Managerial hypotheses of Berger and DeYoung (1997) and Rossi et al. (2009)

\begin{tabular}{llll}
\hline Hypotheses & Dependent variables & Independent variables & Signs \\
\hline Bad luck & Cost efficiency & Lag of insolvency risk & Negative \\
Bad management & Insolvency risk & Lag of cost efficiency & Negative \\
Skimping & Insolvency risk & Lag of cost efficiency & Positive \\
Moral hazard & Insolvency risk & Lag of capital ratio & Negative \\
Classical diversification & Insolvency risk & Lag of diversification & Negative \\
Lack of expertise & Insolvency risk & Lag of diversification & Positive \\
Monitoring & Cost efficiency & Lag of diversification & Negative \\
Idiosyncratic risk & Cost efficiency & Lag of diversification & Positive \\
Economic capital & Capital ratio & Lag of diversification & Negative \\
\hline
\end{tabular}

Similar to Berger and DeYoung (1997), Rossi et al. (2009) used the Granger causality test and the sign of the diversification parameter to identify five additional hypotheses (see Table 2). In particular, if diversification Granger-causes insolvency risk, a negative parameter supports the "classical diversification" hypothesis, while a positive parameter supports the "lack of expertise" hypothesis. When diversification Granger-causes cost efficiency, a negative parameter supports the "monitoring” hypothesis and a positive parameter supports 
the "idiosyncratic" hypothesis. Finally, the "economic capital” hypothesis is supported when diversification Granger-causes capital ratio with a negative parameter.

Overall, Berger and DeYoung (1997) and Rossi et al. (2009) proposed nine managerial hypotheses based on the dynamic interrelationships between diversification, cost efficiency, risk and capital. The Granger causality test is the main approach used to test these hypotheses via the significance and the signs of relevant parameters. Although these hypotheses were developed based on finance theories, they are in line with economics theories. For example, economy of scope and economy of scale help explain diversification hypotheses while the principal agent theory can explain moral hazard, skimping and bad management.

\section{b) Empirical studies}

\section{Berger and DeYoung's hypotheses}

The literature on the interrelationships between cost efficiency, risk and capitalisation in banking is vast, but we found only a limited number of studies which test the above management hypotheses. Moreover, there was no consensus among the findings of these studies. In their pioneer study, Berger and DeYoung (1997) found significant evidence to support all four hypotheses in US banks. They estimated three equations (nonperforming loans, cost efficiency, and capital) separately using ordinary least squares (OLS). Because all three equations contain lag dependent variables and lag of covariates, we believe that a generalised method of moments (GMM) estimator would be more relevant (Bond, 2002).

Kwan and Eisenbeis (1997) applied a simultaneous equation estimator to test the behaviour hypotheses using the quarterly data of US banks. They also estimated the cost efficiency for each time period separately, thus could not measure technological progress. They confirmed only "moral hazard” behaviour, but in contrast to Berger and DeYoung (1997) they attributed this behaviour to the positive relationship between efficiency ${ }^{1}$ and risk. The authors attributed the negative effects of efficiency on capital to regulatory pressure, which Berger and DeYoung (1997) did not consider. Another difference is that Kwan and Eisenbeis (1997) include static equations (i.e., used no lag dependent variables as regressors) rather than dynamic specification, as Berger and DeYoung (1997) did.

\footnotetext{
${ }^{1}$ They refer to this as "negative effects of inefficiency" but we rephrase it as "positive effects of efficiency" to make it comparable with Berger and DeYoung’s (1997) hypotheses.
} 
Williams (2004) applied the framework of Berger and DeYoung (1997) to European banks and found significant evidence to support the "bad management" hypothesis. The author found no evidence of "skimping” behaviour in European banks, although profit efficiency rather than cost efficiency was used as a covariate, according to the original model proposed by Berger and DeYoung. Williams (2004) also found that the results of the test for managerial behaviour were sensitive to the number of lags; an increase in the number of lags raised the goodness of fit, but reduced the significance of the test for managerial behaviour.

Fiordelisi et al. (2011) found evidence of "bad management” behaviour in European banks using the Granger causality test. They also found that an increase in capital Granger caused an improvement in efficiency, which Berger and DeYoung (1997) did not take into account. We argue that the main reason for this finding is scale economy, which bank managers may have difficulty of controlling in the short term. Similarly, Altunbas et al. (2007) revealed insignificant evidence to support "moral hazard” behaviour. In contrast, in European banks they found a positive relationship between capital and risk. The authors argued that the European regulators should use capital as a means of restricting risk-taking behaviour.

Several studies into the managerial behaviour of banks in Asia are reviewed, but the results are also mixed. Deelchand and Padgett (2010) and Reddy (2011) found significant evidence of "bad management”, "moral hazard” and "bad luck” in Japanese and Indian banks, while Tan and Floros (2013) found only "bad management" behaviour in Chinese commercial banks. One factor which contributes to the differences is the methodology used in the studies. Deelchand and Padgett (2010) and Tan and Floros (2013) applied, respectively, two- and three-stage least squares while Reddy used the Granger causality test. Also, most of these studies did not perform tests on the sensitivity of their results to choice of variables or methods.

\section{Rossi et al.'s hypothesis}

We planned to review studies into managerial hypotheses based on the framework by Rossi et al. (2009), but despite our extensive search, no relevant study was found. Thus, in this section we focus on reviewing selected studies into the effect of bank diversification on risk, cost efficiency and capital, because these relationships are the essence of Rossi et al.'s hypotheses. In their pioneering study of Austrian banks from 1997 to 2003, Rossi et al. (2009) found that diversification was negatively associated with cost efficiency (supporting 
“monitoring” behaviour) while positively associated with profit efficiency. Austrian banks also revealed "classical diversification” behaviour (diversification was associated with reduced risk), and diversification was positively associated with capital. They applied the Fourier flexible form of production function, which is very flexible but does not have the convenient properties of the translog function to allow the authors to estimate total factor productivity changes and its components (i.e., technical progress, scale changes and efficiency changes).

Elyasiani and Wang (2012) examined the effects of diversification on the operational efficiency of 161 commercial banks in the US from 1997 to 2007. They applied data envelopment analysis (DEA) to calculate technical efficiency (and its components), and measured the effect of diversification via a second stage regression. They found that revenue diversification over time was negatively associated with technical efficiency changes. Based on Rossi et al.'s (2009) study, the negative association between diversification and production efficiency suggests that US banks in the sample experienced "monitoring" behaviour.

In Asia, Lee et al. (2014) reported that revenue diversification did not exert an impact on the profitability of banks in Asia, including Vietnam, over the period 1995-2009, providing no evidence to support or reject the "monitoring" and "idiosyncratic risk" behaviour. The authors also documented a positive impact of the ratio of loans to total earning assets on the risk of these banks, i.e. a negative impact of earning assets diversification on bank risk, and hence evidencing the support of the "classical diversification" behaviour. In constrast, Meslier et al. (2014) revealed that revenue diversification was associated with increased profits, and this benefit was greater for foreign banks compared to their domestic counterparts in the Philippines from 1999 to 2005.

There are several studies into the performance of Vietnamese banks, including those by Nguyen et al. (2016), Nguyen et al. (2014), Vu and Nahm (2013), and Vu and Turnell (2010), but these studies focus only on estimating the efficiency and its determinants, of Vietnamese banks. In particular, Nguyen et al. (2016) compared the cost efficiency of Vietnamese banks with that of Chinese and Indian banks, and found that Vietnamese banks are the least cost efficient, followed by Chinese banks and Indian banks. Nguyen et al. (2014) analysed the cost and profit efficiency of the Vietnamese banking sector over the period 1995 
to 2011 taking into account the Asian and Global Financial crises. The authors observed that the cost and profit efficiency of the Vietnamese banking system averaged around 0.90 and 0.75, respectively, and that the Global Financial Crisis (GFC) and Asian Financial Crisis (AFC) did not significantly affect the efficiency of the whole banking system. Vu and Nahm (2013) explored the determinants of the profit efficiency of Vietnamese banks from 2000 to 2006. The authors documented that bank size, management ability, growth of GDP per capita rate have positive effects, while asset quality, capitalisation and inflation rate have negative impacts on efficiency. $\mathrm{Vu}$ and Turnell (2010) investigated the cost efficiency of the Vietnamese banking industry, and found that the level of its cost efficiency at around 87 percent, with insignificant differences between different groups of banks classified by ownership, and with a slightly declining trend over the period 2000-2006.

Overall, despite the vast amount of literature on banking performance, we found only a handful of studies which examined the interrelationship between efficiency, risk and capital, as well as the effects of diversification on these factors, using the framework of managerial behaviours by Berger and DeYoung (1997) and Rossi et al. (2009). No previous studies have investigated this issue in the Vietnamese banking industry. Also, most previous stochastic frontier analysis (SFA) studies did not conduct tests on the robustness of their results. This study fills the gap in the literature by investigating managerial behaviours in Vietnamese banks based on the managerial framework proposed by Berger and DeYoung (1997) and Rossi et al. (2009). We also test for the robustness of results by using an alternative risk measurement, an alternative efficiency SFA model and controlling for unobserved bank heterogeneity.

\section{Methodology}

\section{a) Diversification index}

This study measures bank diversification from the aspects of revenue and earning assets using the Herfindahl-Hirschman Index (HHI) approach which is widely used in the literature (Chiorazzo et al., 2008; Elsas et al., 2010; Goddard et al., 2008; Hayden et al., 2007; Mercieca et al., 2007; Meslier et al., 2014). Originally, the HHI, measured as the sum of squares of market share of firms, is used to indicate market concentration in a variety of contexts (Rhoades, 1993). The main advantage of the HHI is that it gives more weight to larger firms. When the HHI is measured by the sum of squares of the share of revenue 
sources, the HHI index indicates the concentration of revenue sources, and hence one minus the HHI reflects the diversification of revenue. As this study focuses on a diversity of revenue across two different sources, interest and non-interest revenue, the diversification index is calculated as follows:

$$
\text { Diversification index }_{\text {revenue }}=1-\sum_{i=1}^{2}\left(L_{i} / Q\right)^{2}
$$

where $L_{1}$ is non-interest revenue; $L_{2}$ is interest revenue; and $Q$ is the sum of $L_{1}$ and $L_{2}$.

Similarly, diversification of earning assets reflects the diversity of earning assets across two different categories, lending and non-lending earning assets. This diversification index is computed as follows:

$$
\text { Diversification index } x_{\text {earning assets }}=1-\sum_{i=1}^{2}\left(S_{i} / K\right)^{2}
$$

where $S_{1}$ is gross loans; $S_{2}$ is other earning assets; and $K$ is total earning assets (the sum of $S_{1}$ and $S_{2}$ ).

The diversification index ranges from zero to one, with higher values indicating a greater level of diversification.

\section{b) Efficiency estimation}

Efficiency is widely estimated by the use of either Stochastic Frontier Analysis (SFA) proposed by Aigner et al. (1977) and Meeusen and Van den Broeck (1977) or Data Envelopment Analysis (DEA) proposed by Charnes et al. (1978). SFA and DEA are different in the way they deal with statistical noise: SFA includes statistical noise in the error term, while DEA assumes no statistical noise. That is, DEA does not consider measurement error and luck as factors affecting efficiency estimates. Any deviation from the frontier is assumed to reflect inefficiency. If measurement errors exist, they would be reflected in a change of measured efficiency., Any of these errors in one of the banks on the efficient frontier may change the measured efficiency of all banks (Berger and Humphrey, 1997). Since banking data on emerging countries like Vietnam are more likely to have measurement errors and 
statistical noise, we select SFA to estimate the efficiency of Vietnamese banks. The empirical specification of the cost frontier for the Vietnamese banking system is as follows:

$$
\ln C_{i t}=\alpha+\beta X_{i t}+v_{i t}+u_{i t}
$$

where $\ln C_{i t}$ denotes the natural logarithm of total cost for bank $i$ in year $t ; X_{i t}$ denotes a set of output, input price, and time variables; $\alpha$ and $\beta$ are unknown parameters to be estimated; and $\left(v_{i t}+u_{i t}\right)$ is the composite error term, which consists of the statistical noise $v_{i t}$ and the non-negative component $u_{i t}$ that captures the inefficiency. The cost efficiency (CE) scores of banks are calculated as $C E_{i t}=\exp \left(-u_{i t}\right)$. CE will range from zero (very poorly operated banks) to one (best practice banks).

Following Fiordelisi et al. (2011), Deelchand and Padgett (2010), Nguyen et al. (2014) and Gardener et al. (2011), this study adopts the intermediation approach taken by Sealey and Lindley (1977) to measure the efficiency of banks. In particular, this study specifies that banks use three inputs (deposits, physical capital and personnel) to produce two outputs, namely loans $\left(Y_{1}\right)$ and other earning assets $\left(Y_{2}\right)$. This study calculates the price of the three inputs as the ratio of interest expenses to total funding $\left(W_{1}\right)$, the ratio of other operating expenses to fixed assets $\left(W_{2}\right)$ and the ratio of personnel expenses to total assets $\left(W_{3}\right)$.

To estimate the stochastic frontier model, this study needs to assume a functional form to model the production function of banks. The banking efficiency literature reveals some common functional forms: the Cobb-Douglas, translog and Fourier-flexible, but the translog function appears to be the most widely-used. Restrictions regarding the function of the stochastic cost frontier are more flexible when a translog functional form is applied than when a Cobb-Douglas functional form is applied, as it allows for interactions among outputs and input prices (Battese et al., 2000). Also, the translog functional form also relaxes the assumption in a Cobb-Douglas function that the elasticity of subsistituion equals to unity. Altunbaş and Chakravarty (2001) identified some statistical problems associated with Fourier-flexible function, especially when dealing with heterogeneous datasets. Meanwhile, Vietnamese banks are much different in size, heteroskedasticity may be a concern in their dataset. Therefore, this study selects the translog functional form to specify the stochastic cost frontier. This study imposes linear homogeneity restrictions by normalising the dependent variable and input price variables by the labour price $\left(W_{3}\right)$. It also includes a time 
trend $(t)$ to proxy technological progress over time ( $t=1$ for 2000 , $t=2$ for $2001, . ., t=15$ for 2014). Thus, in Equation 3 the translog cost function for estimation of cost efficiency in this study is specified as follows (subscripts $i$ and $t$ are dropped for ease of viewing):

$$
\begin{aligned}
\ln \left(C / W_{3}\right)= & \alpha_{0}+\sum_{m=1}^{2} \alpha_{m} \ln Y_{m}+\frac{1}{2} \sum_{m=1}^{2} \sum_{k=1}^{2} \alpha_{m k} \ln Y_{m} \ln Y_{k}+\sum_{n=1}^{2} \beta_{n} \ln \left(W_{n} / W_{3}\right) \\
& +\frac{1}{2} \sum_{n=1}^{2} \sum_{l=1}^{2} \beta_{n l} \ln \left(W_{n} / W_{3}\right) \ln \left(W_{l} / W_{3}\right)+\frac{1}{2} \sum_{m=1}^{2} \sum_{n=1}^{2} \delta_{m n} \ln Y_{m} \ln \left(W_{n} / W_{3}\right) \\
& +\gamma_{1} t+\frac{1}{2} \gamma_{2} t^{2}+\sum_{m=1}^{2} \gamma_{2+m} t \ln Y_{m}+\sum_{n=1}^{2} \gamma_{4+n} t \ln \left(W_{n} / W_{3}\right)+v+u
\end{aligned}
$$

As Vietnamese banks differ considerably in size, Equation 4 is estimated using the true fixed effects models developed by Greene (2005) to control for unobserved individual heterogeneity.

\section{c) Risk measurement}

Following studies such as those undertaken by Tan and Floros (2013), Beck et al. (2013), Demirgüç-Kunt and Huizinga (2010), Houston et al. (2010) and Laeven and Levine (2009), this study primarily measures bank risk using the Z-score proposed by Roy (1952), which reflects the distance to insolvency, calculated as follows:

$$
Z_{i t}=\frac{R O A_{i t}+E T A_{i t}}{\sigma_{R O A_{i}}}
$$

where $Z_{i t}$ is the Z-score of bank $i$ in year $t$; $E T A_{i t}$ is the capital ratio of bank $i$ in year $t$ which is computed by the ratio of total equity to total assets; $\sigma_{R O A_{I}}$ is the standard deviation of return on assets of bank $i$. A higher level of Z-score implies lower insolvency probability.

Moreover, as average outstanding lending accounts for approximately $61 \%$ of the earning assets of Vietnamese banks, credit risks are more likely to be the main cause of insolvency risk. Therefore, we also measure the risk of Vietnamese banks using the ratio of loan loss provision to gross loans.

\section{d) Managerial behaviour model}


Based on Rossi et al. (2009) study, we investigate the interrelationship between efficiency, risk and capital, and the effects of bank diversification on the three variables in order to identify management behaviours. However, instead of using the Granger causality test to examine the causal relationship of these variables, we estimate a system of three equations simultaneously, as follows:

$$
\begin{aligned}
& \text { Risk }_{i t} \quad=\propto_{0}+\propto_{1} \text { Diversification }_{i t}+\propto_{2} \text { Efficiency }_{i t}+\propto_{3} \text { Capital }_{i t}+ \\
& \alpha_{4} \text { Size }_{i t}+\propto_{5} \text { GDP Growth } i t+\omega_{i t} \\
& \text { Capital }_{i t}=\beta_{0}+\beta_{1} \text { Diversification }_{i t}+\beta_{2} \text { Efficiency }_{i t}+\beta_{3} \text { Risk }_{i t}+\beta_{4} \text { Size }_{i t}+ \\
& \beta_{5} \text { GDP Growth } \text { it }+\epsilon_{i t} \\
& \text { Efficiency }_{i t}=\gamma_{0}+\gamma_{1} \text { Diversification }_{i t}+\gamma_{2} \text { Risk }+\gamma_{3} \text { Capital }_{i t}+\gamma_{4} \text { Size }_{i t}+ \\
& \gamma_{5} G D P \text { Growth }_{i t}+\theta_{i t}
\end{aligned}
$$

where Risk is measured by Z-score; Capital is measured by the ratio of total equity to total assets; Efficiency is the cost efficiency scores; Size is measured by total assets; Diversification is measured by the diversification index in Equations 1 and 2. As the distribution of the Z-score is highly skewed, this study uses the natural logarithm of the Zscore to reduce the skewness.

Equation 6 explores the effects of diversification, efficiency and capital on insolvency risk. Since a higher Z-score implies lower risk, a negative $\propto_{1}$ supports "lack of expertise" behaviour while a positive $\propto_{1}$ supports “classical diversification” behaviour. A negative $\propto_{2}$ confirms "skimping” behaviour while a positive $\propto_{2}$ suggests "bad management” behaviour. A positive $\propto_{3}$ for a sample of poorly capitalised banks supports "moral hazard" behaviour. Equation 7 examines the effect of diversification on bank capital. A negative $\beta_{1}$ confirms “economic capital” behaviour. Equation 8 investigates the impact of diversification and risk on cost efficiency. Specifically, a negative $\gamma_{1}$ supports "monitoring” behaviour while a positive $\gamma_{1}$ reveals “idiosyncratic risk" behaviour. A positive $\gamma_{2}$ confirms "bad luck" behaviour.

Several methods were used to estimate the managerial behaviour model: i) Granger causality (Berger and DeYoung, 1997; Fiordelisi et al., 2011; Rossi et al., 2009; Williams, 2004); ii) SUR (Altunbas et al., 2007); iii) two-stage least squares (2SLS) (Deelchand and Padgett, 2010; Kwan and Eisenbeis, 1997); and iv) three-stage least squares (3SLS) (Tan and Floros, 
2013). The Granger causality test does not consider the effects of other variables and the results are sensitive to the number of lags. The 2SLS ignores the correlations of the error terms across the equations while the seemingly unrelated regressions (SUR) assumes that all regressors are exogenous, although it takes into account the correlation of error terms across equations. This study estimates Equations 6 to 8 by the 3SLS method introduced by Zellner and Theil (1962), which adds the third step to the 2SLS method to account for the correlation of residuals across equations. Specifically, in the first stage the reduced form of the model is estimated. In the second stage, the fitted values of the endogenous variables are used to estimate Equations 6 to 8. In the third stage, generalised least squares parameters are obtained. In this study, risk, capital and efficiency are defined as dependent variables of the managerial model (i.e., endogenous variables); other variables, including diversification, size and gross domestic product (GDP) growth, are defined as exogenous variables, which are used as instrumental variables for endogenous variables.

This study also checks for the robustness of the results of management behaviour by using an alternative SFA estimation technique proposed by Battese and Coelli (1995) to estimate cost efficiency and an alternative risk measurements (the loan loss provision ratio).

\section{e) Data}

This study focuses only on Vietnamese local commercial banks (i.e., state-owned commercial banks and joint-stock commercial banks) as data on joint-venture/foreign banks cannot be obtained. Moreover, foreign banks account for less than $11.30 \%$ of the banking market and may operate under different production technology to local banks, as these banks were much more restricted in doing business than local banks. The data was collected from the Bankscope database. The sample consists of 32 local commercial banks from 2000 to 2014, including all four state-owned commercial banks and 28 main joint-stock commercial banks, which represent more than $95 \%$ of the local banking market in terms of deposits. These data form an unbalanced panel, with total observations of 360 .

Table 3 shows descriptive statistics for variables used for estimating bank diversification, risk and efficiency and testing managerial behaviour in Vietnamese banks. It can be seen that over the period 2000 to 2014, interest income accounts for $91.3 \%$ of total income while gross loans take up $61.4 \%$ of total earning assets, and hence the diversification index is smaller than 0.5 (only 0.15 for revenue and 0.41 for earning assets). This indicates that lending is the 
major earning activity and the major income source for Vietnamese local banks. Other bankspecific variables indicate that the average annual cost for mobilising funds is $6.2 \%$; the average return on assets is $1.3 \%$; the average ratio of total equity to total assets is $10.93 \%$; and the average loan loss provision ratio is $0.84 \%$. Also, the average annual GDP growth rate is $6.29 \%$.

Table 3: Descriptive statistics

\begin{tabular}{|c|c|c|c|}
\hline Variables & Descriptions & Mean & Std dev \\
\hline \multicolumn{4}{|c|}{ A. Variables used for computing diversification index } \\
\hline Interest revenue ratio & Computed by the ratio of interest revenue to total revenue & 0.913 & 0.065 \\
\hline $\begin{array}{l}\text { Non-interest revenue } \\
\text { ratio }\end{array}$ & Computed by the ratio of non-interest revenue to total revenue & 0.087 & 0.065 \\
\hline $\begin{array}{l}\text { Revenue diversification } \\
\text { index }\end{array}$ & $\begin{array}{l}\text { A measure of diversification of revenue across two different } \\
\text { sources: interest revenue and non-interest revenue as Eq. (1) }\end{array}$ & 0.151 & 0.100 \\
\hline $\begin{array}{l}\text { Lending earning assets } \\
\text { ratio }\end{array}$ & Computed by the ratio of gross loans to total earning assets & 0.614 & 0.177 \\
\hline $\begin{array}{l}\text { Non-lending earning } \\
\text { assets ratio }\end{array}$ & Computed by the ratio of other earning assets to total earning assets & 0.386 & 0.177 \\
\hline $\begin{array}{l}\text { Earning assets } \\
\text { diversification index }\end{array}$ & $\begin{array}{l}\text { A measure of diversification of earning assets across two different } \\
\text { sources: lending and non-lending earning assets as Eq. (2) }\end{array}$ & 0.411 & 0.096 \\
\hline \multicolumn{4}{|c|}{ B. Variables used for estimating cost efficiency scores } \\
\hline TC (Total Cost) & $\begin{array}{l}\text { The sum of interest expenses, other operating expenses and } \\
\text { personnel expenses (million \$US) }\end{array}$ & \multicolumn{2}{|l|}{$2,977.373$} \\
\hline $\mathrm{Y}_{1}$ (Output 1) & $\begin{array}{l}\text { Net loans measured by gross loans minus reserves for impaired } \\
\text { loans (million \$US) }\end{array}$ & \multicolumn{2}{|c|}{$24,979.66040,695.180$} \\
\hline $\mathrm{Y}_{2}$ (Output 2) & $\begin{array}{l}\text { Other earning assets measured by security investments and other } \\
\text { earning assets (million \$US) }\end{array}$ & \multicolumn{2}{|c|}{$13,479.32016,789.160$} \\
\hline $\mathrm{W}_{1}$ (Price of input 1 ) & $\begin{array}{l}\text { Financial capital price calculated by the ratio of interest expenses to } \\
\text { total funding }\end{array}$ & 0.062 & 0.026 \\
\hline $\mathrm{W}_{2}$ (Price of input 2) & $\begin{array}{l}\text { Physical capital price computed by the ratio of other operating } \\
\text { expenses to fixed assets }\end{array}$ & 1.288 & 1.070 \\
\hline $\mathrm{W}_{3}$ (Price of input 3) & $\begin{array}{l}\text { Labour price which is measured by the ratio of personnel expenses } \\
\text { to total assets }\end{array}$ & 0.007 & 0.007 \\
\hline \multicolumn{4}{|c|}{ C. Variables used for measuring bank risk } \\
\hline $\mathrm{ROA}$ & Computed by the profit before tax to total assets & 0.013 & 0.009 \\
\hline ETA & $\begin{array}{l}\text { The capital ratio measured by the ratio of total equity to total assets } \\
\text { (\%) }\end{array}$ & 10.932 & 7.971 \\
\hline$\sigma(\mathrm{ROA})$ & Calculated by the standard deviation of ROA & 0.007 & 0.004 \\
\hline LnZ-score & A logarithm of Z-score computed as Eq. (5) & 8.288 & 0.326 \\
\hline \multicolumn{2}{|c|}{ Loan loss provision ratio computed by the ratio of loan loss provision to gross loans (\%) } & 0.845 & 0.816 \\
\hline \multicolumn{4}{|c|}{ D. Control variables for testing managerial hypotheses } \\
\hline Size & A natural logarithm of total assets which captures bank size & 9.789 & 1.420 \\
\hline
\end{tabular}


Data on bank-specific variables are from Bankscope; standard deviation in parentheses; data on GDP growth are from World bank database;

\section{Empirical results}

\section{a) Efficiency analysis}

Table 4: Cost function (SFA estimates)

\begin{tabular}{|c|c|c|}
\hline \multirow{2}{*}{ Variables } & \multicolumn{2}{|l|}{ Cost function } \\
\hline & $\overline{\text { Coef. }}$ & Std. Err. \\
\hline$\overline{\text { Log of net loan }\left(\operatorname{lny}_{1}\right)}$ & $0.6115^{* * *}$ & $(0.0155)$ \\
\hline Log of other earning asset $\left(\operatorname{lny}_{2}\right)$ & $0.5093^{* * *}$ & $(0.0507)$ \\
\hline Log of price ratio of financial capital/ labour $\left(\operatorname{lnw}_{1} / \mathrm{w}_{3}\right)$ & $0.4235^{* * *}$ & $(0.1359)$ \\
\hline Log of price ratio of physical capital /labour $\left(\ln _{2} / \mathrm{w}_{3}\right)$ & 0.0283 & $(0.1514)$ \\
\hline Time trend $(\mathrm{t})$ & -0.0272 & $(0.0177)$ \\
\hline$\left(\operatorname{lng} y_{1}\right)^{2}$ & $0.2189 * * *$ & $(0.0311)$ \\
\hline $\operatorname{lny}_{1} * \ln y_{2}$ & $-0.2202^{* * *}$ & $(0.0095)$ \\
\hline $\operatorname{lny}_{1} * \ln _{1} / w_{3}$ & -0.0191 & $(0.0263)$ \\
\hline $\operatorname{lny}_{1} * \operatorname{lnw}_{2} / w_{3}$ & 0.0039 & $(0.0221)$ \\
\hline $\operatorname{lny}_{1} * \mathrm{t}$ & $-0.0092 * * *$ & $(0.0011)$ \\
\hline$\left(\ln y_{2}\right)^{2}$ & $0.1988^{* * *}$ & $(0.0059)$ \\
\hline $\operatorname{lny}_{2} * \ln _{1} / w_{3}$ & $0.0445^{*}$ & $(0.0270)$ \\
\hline $\operatorname{lny}_{2} * \operatorname{lnw}_{2} / \mathrm{w}_{3}$ & -0.0004 & $(0.0172)$ \\
\hline $\operatorname{lny}_{2} * \mathrm{t}$ & $0.0105^{* * *}$ & $(0.0022)$ \\
\hline$\left(\operatorname{lnw}_{1} / \mathrm{w}_{3}\right)^{2}$ & $0.1376 * *$ & $(0.0679)$ \\
\hline $\operatorname{lnw}_{1} / \mathrm{w}_{3} * \operatorname{lnw}_{2} / \mathrm{w}_{3}$ & $-0.0352^{* *}$ & $(0.0143)$ \\
\hline $\ln \mathrm{w}_{1} / \mathrm{w}_{3}{ }^{* \mathrm{t}}$ & 0.0017 & $(0.0038)$ \\
\hline$\left(\operatorname{lnw}_{2} / \mathrm{w}_{3}\right)^{2}$ & 0.0169 & $(0.0265)$ \\
\hline $\ln w_{2} / w_{3} * t$ & -0.0024 & $(0.0020)$ \\
\hline$t^{2}$ & $0.0027^{* * *}$ & $(0.0007)$ \\
\hline Constant & $-3.6940 * *$ & $(1.6803)$ \\
\hline$\sigma_{\mathrm{u}}$ & $0.6338 * * *$ & 0.1376 \\
\hline$\gamma\left(\sigma_{u /} \sigma_{v}\right)$ & $1815.612 * * *$ & 0.0002 \\
\hline
\end{tabular}

The parameter $\gamma$ (ratio of standard deviation of inefficiency to that of random noise, known as the signal-to-noise ratio) and $\sigma_{\mathrm{u}}$ (standard deviation of inefficiency) indicates significant evidence that cost inefficiency explained differences of bank costs in Vietnam (see Table 4). Parameters for bank outputs (Iny $y_{1}$ and $\left.\ln y_{2}\right)$ and price of financial capital $\left(\ln w_{1} / w_{3}\right)$ are statistically significant and positive, indicating that loans and non-lending earning assets are positively associated with costs. In particular, a $1 \%$ increase in loans is associated with a $0.61 \%$ increase in costs, while the relative figure of a $1 \%$ increase in non-lending assets is $0.50 \%$ and the relative figure of a $1 \%$ increase in price of financial capital is $0.42 \%$. 
Parameter time trend $(t)$ is statistically insignificant, suggesting that in total, Vietnamese banks' costs have experienced an unclear trend during the period 2000 to 2014. It should be noted that to precisely measure the trend in cost over time, one needs to take into account the quadratic term of the time trend $\left(t^{2}\right)$ and interaction terms between $(\mathrm{t})$ and other variables. Overall, the outputs and input price have a significant impact on the total costs to Vietnamese banks, implying that the cost function for Vietnamese banks was well specified.

Figure 1 shows that the average cost efficiency of the Vietnamese banking system reveals an unclear trend over the period 2000 to 2014, confirming the finding from the SFA estimates In particular, the analysis period displays an upward trend in the first half, but a downward trend in the second half of the period. The fall in the cost efficiency during the period 2007 to 2009 could be due to the influence of the 2007-2009 global financial crisis. The period averaged cost efficiency of Vietnamese banks is 0.908 , suggesting that they could reduce $9.2 \%$ of their operating costs while producing the same level of outputs. The everage cost-efficiency score of 0.91 is in-line with the average cost-efficiency score of 0.90 in Nguyen et al. (2014) on Vietnamese banks over the period 1995-2011, and a similar score of 0.87 in Vu and Turnell (2010) on these banks from 2000 to 2006. Overall, the finding of this study supports the view of a high cost efficiency in the Vietnamese banking industry.

Figure 1: Cost efficiency, 2000-2015

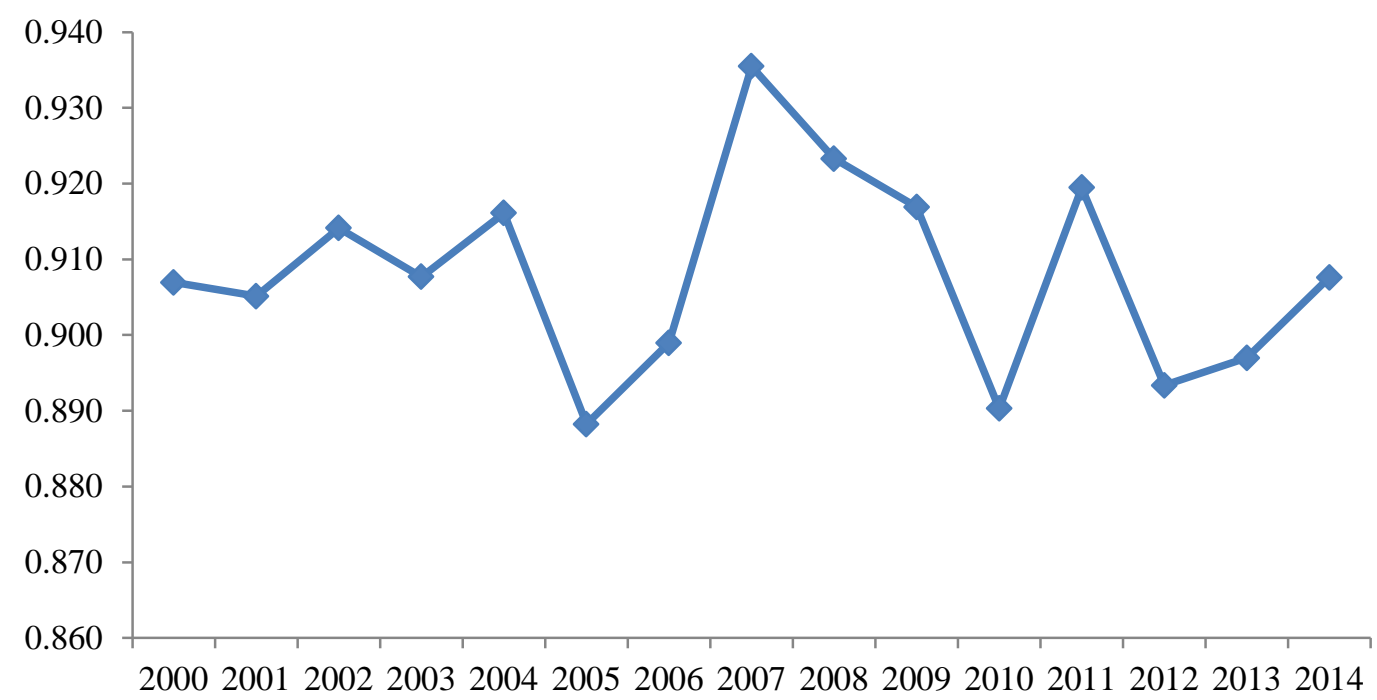




\section{b) Tests for hypotheses on managerial behaviours}

Table 5 presents the estimates of Equations 6 to 8 using the 3SLS estimator, where bank diversification is measured in terms of revenue, while Table 6 presents the relative estimates where bank diversification is measured in terms of earning assets. The main model (risk is measured by the Z-score and cost efficiency is estimated by Greene (2005) true-effect SFA model) is indicated in Columns 1 and 2. Models of sensitivity tests are indicated in Columns 3 and 4 (risk is measured by the minus loan loss provision ratio) and Columns 5 and 6 (cost efficiency is estimated by Battese and Coelli (1995) SFA model). We now focus on discussing the results of the main model (the first two columns of Tables 5 and 6).

The results for Equation 6 show that revenue diversification $\left(\propto_{1}\right)$ is statistically insignificant, but earning assets diversification $\left(\propto_{1}\right)$ is statistically significant and positive (note that a higher Z-score implies a lower risk). This provides evidence of a negative impact of diversification of earning assets on insolvency risk, supporting the "classical diversification" hypothesis. The significant and positive parameter of cost efficiency $\left(\propto_{2}\right)$ shows that a decline in cost efficiency leads to an increase in insolvency risk, thereby supporting "bad management” behaviour. The significant and positive parameter of capital ratio $\left(\propto_{3}\right)$ suggests that a decline in capital is associated with a rise in insolvency risk, providing evidence for "moral hazard" behaviour. The negative parameter of bank size $\left(\propto_{4}\right)$ (insignificant in Table 5 but significant in Table 6) shows that larger banks have higher insolvency risk, which could be due to the fact that Vietnamese banks may have relaxed the criteria for screening and monitoring portfolios of loans and investments when they expanded loans and security investments so quickly during the analysis period. The positive and significant parameter of GDP growth $\left(\propto_{4}\right)$ shows that insolvency risk reduces when the Vietnamese economy performs better.

Regarding Equation 7, revenue diversification $\left(\beta_{1}\right)$ has an insignificant effect on the capital ratio, but earning assets diversification $\left(\beta_{1}\right)$ has a negative and significant impact as expected, supporting the "economic capital" hypothesis. Cost efficiency $\left(\beta_{2}\right)$ has a significant and negative impact on the capital ratio. Banks often respond to deterioration in cost efficiency by raising capital (numerator of capital ratio) as a precautionary step. The positive and significant coefficient of Z-score $\left(\beta_{3}\right)$ could be because banks with a low risk portfolio (i.e., a higher Z-score) can attract more capital (i.e., improve capital ratio). Larger 
banks $\left(\beta_{4}\right)$ are found to operate with lower capital ratios, which could be because in Vietnamese banks, the speed of raising capital (numerator of capital ratio) is lower than the speed of expansion of total assets (denominator of capital ratio), and hence when total assets (bank size) increase, the ratio of capital to total assets decreases. Banks which are operating in a better economy may have expanded their loans and security investments (the main part of the denominator of capital ratio), leading to a lower capital ratio (a significant and negative parameter of GDP growth $\left(\beta_{5}\right)$ )

Table 5: Tests for hypothesis on managerial behaviours (except moral hazard) when bank diversification is measured from the aspect of revenue

\begin{tabular}{|c|c|c|c|c|c|c|}
\hline \multirow{3}{*}{$\begin{array}{l}\text { Risk measurement } \\
\text { Efficiency estimation } \\
\text { technique } \\
\text { Column }\end{array}$} & \multirow{2}{*}{\multicolumn{2}{|c|}{$\begin{array}{c}\text { Risk = Z-score } \\
\begin{array}{c}\text { SFA Green (2005) } \\
\text { model }\end{array}\end{array}$}} & \multirow{2}{*}{\multicolumn{2}{|c|}{$\begin{array}{c}\text { Risk = minus loan loss } \\
\text { provision ratio }\end{array}$}} & \multirow{2}{*}{\multicolumn{2}{|c|}{$\begin{array}{c}\text { Risk = Z-score } \\
\text { SFA Battese and } \\
\text { Coelli (1995) model }\end{array}$}} \\
\hline & & & & & & \\
\hline & $\begin{array}{l}\text { Coef. } \\
\text { (1) }\end{array}$ & $\begin{array}{c}\text { Std. Err } \\
(2)\end{array}$ & $\begin{array}{l}\text { Coef. } \\
\text { (3) }\end{array}$ & $\begin{array}{c}\text { Std. Err } \\
\text { (4) }\end{array}$ & $\begin{array}{l}\text { Coef. } \\
\text { (5) }\end{array}$ & $\begin{array}{c}\text { Std. Err } \\
(6)\end{array}$ \\
\hline \multicolumn{7}{|c|}{ Dependent variable is Risk (Eq. 6) } \\
\hline Revenue Div. $\left(\propto_{1}\right)$ & 0.2378 & $(0.2068)$ & 0.7020 & $(0.5963)$ & $0.6090^{* * *}$ & $(0.1914)$ \\
\hline Efficiency $\left(\propto_{2}\right)$ & $2.6480^{* * *}$ & $(0.3460)$ & $7.1579 * * *$ & $(0.2464)$ & $5.6617^{* * *}$ & $(0.3307)$ \\
\hline Capital $\left(\propto_{3}\right)$ & $4.4396 * * *$ & $(0.7793)$ & $6.0034 * * *$ & $(0.7204)$ & $3.3493 * * *$ & $(0.4085)$ \\
\hline Size $\propto_{4}$ & -0.0086 & $(0.0234)$ & -0.0544 & $(0.0452)$ & $-0.0321 *$ & $(0.0165)$ \\
\hline GDP growth $\left(\propto_{5}\right)$ & $0.1601^{* * *}$ & $(0.0465)$ & $0.5725 * * *$ & $(0.0879)$ & $0.1067 * * *$ & $(0.0322)$ \\
\hline Constant & $4.4828^{* * *}$ & $(0.7379)$ & $-11.1169^{* * *}$ & $(0.9349)$ & $2.1715^{* * *}$ & $(0.5143)$ \\
\hline \multicolumn{7}{|c|}{ Dependent variable is Capital (Eq. 7) } \\
\hline Revenue Div. $\left(\beta_{1}\right)$ & -0.0538 & $(0.0447)$ & -0.1169 & $(0.0989)$ & $-0.1817 * * *$ & $(0.0568)$ \\
\hline Efficiency $\left(\beta_{2}\right)$ & $-0.5939 * * *$ & $(0.0817)$ & $-1.1922^{* * *}$ & $(0.1329)$ & $-1.6892 * * *$ & $(0.2008)$ \\
\hline $\operatorname{Risk}\left(\beta_{3}\right)$ & $0.2234 * * *$ & $(0.0378)$ & $0.1665^{* * *}$ & $(0.0210)$ & $0.2984 * * *$ & $(0.0374)$ \\
\hline Size $\left(\beta_{4}\right)$ & 0.0017 & $(0.0053)$ & 0.0091 & $(0.0081)$ & $0.0096 *$ & $(0.0058)$ \\
\hline GDP growth $\left(\beta_{5}\right)$ & $-0.0362 * * *$ & $(0.0064)$ & $-0.0953 * * *$ & $(0.0146)$ & $-0.0319 * * *$ & $(0.0078)$ \\
\hline Constant & $-0.9945^{* * *}$ & $(0.3394)$ & $1.8516^{* * *}$ & $(0.1781)$ & $-0.6480 * * *$ & $(0.2378)$ \\
\hline \multicolumn{7}{|c|}{ Dependent variable is Efficiency (Eq. 8) } \\
\hline Revenue Div. $\left(\gamma_{1}\right)$ & -0.0900 & $(0.0761)$ & -0.0981 & $(0.0832)$ & $-0.1076^{* * *}$ & $(0.0331)$ \\
\hline $\operatorname{Risk}\left(\gamma_{2}\right)$ & $0.3758^{* * *}$ & $(0.0490)$ & $0.1397 * * *$ & $(0.0048)$ & $0.1766^{* * *}$ & $(0.0104)$ \\
\hline Capital $\left(\gamma_{3}\right)$ & $-1.6745^{* * *}$ & $(0.2383)$ & $-0.8387 * * *$ & $(0.0888)$ & $-0.5915^{* * *}$ & $(0.0691)$ \\
\hline Size $\left(\gamma_{4}\right)$ & 0.0031 & $(0.0089)$ & 0.0076 & $(0.0064)$ & $0.0057^{*}$ & $(0.0030)$ \\
\hline GDP growth $\left(\gamma_{5}\right)$ & $-0.0604 * * *$ & $(0.0154)$ & $-0.0800 * * *$ & $(0.0120)$ & $-0.0188 * * *$ & $(0.0056)$ \\
\hline Constant & $-1.6763 * * *$ & $(0.4804)$ & $1.5531 * * *$ & $(0.1147)$ & $-0.3836 * * *$ & $(0.1118)$ \\
\hline No. of observations & 360 & & 360 & & 360 & \\
\hline Chi-squared for Eq. 6 & 124.5581 & & 932.8467 & & 372.9791 & \\
\hline Chi-squared for Eq. 7 & 181.5824 & & 108.5718 & & 152.7718 & \\
\hline Chi-squared for Eq. 8 & 93.5430 & & 1176.6398 & & 334.1088 & \\
\hline
\end{tabular}

$* * *, * *$ and $*: 1 \%, 5 \%$ and $10 \%$ levels of significance, respectively 
Table 6: Tests for hypothesis on managerial behaviours (except moral hazard) when bank diversification is measured from the aspect of earning assets

\begin{tabular}{|c|c|c|c|c|c|c|}
\hline \multirow{3}{*}{$\begin{array}{l}\text { Risk measurement } \\
\text { Efficiency estimation } \\
\text { technique } \\
\text { Column }\end{array}$} & \multicolumn{2}{|c|}{ Risk $=$ Z-score } & \multirow{2}{*}{\multicolumn{2}{|c|}{$\begin{array}{c}\text { Risk = minus loan loss } \\
\text { provision ratio } \\
\text { SFA Green (2005) model }\end{array}$}} & \multicolumn{2}{|c|}{ Risk $=$ Z-score } \\
\hline & \multicolumn{2}{|c|}{$\begin{array}{c}\text { SFA Green (2005) } \\
\text { model }\end{array}$} & & & \multicolumn{2}{|c|}{$\begin{array}{c}\text { SFA Battese and Coell } \\
\text { (1995) model }\end{array}$} \\
\hline & $\begin{array}{l}\text { Coef. } \\
(1)\end{array}$ & $\begin{array}{c}\text { Std. Err } \\
(2)\end{array}$ & $\begin{array}{l}\text { Coef. } \\
(3)\end{array}$ & $\begin{array}{l}\text { Std. Err } \\
(4)\end{array}$ & $\begin{array}{l}\text { Coef. } \\
(5)\end{array}$ & $\begin{array}{l}\text { Std. Err } \\
(6)\end{array}$ \\
\hline \multicolumn{7}{|c|}{ Dependent variable is Risk (Eq. 6) } \\
\hline Earning assets Div. $\left(\propto_{1}\right)$ & $0.4057^{* *}$ & $(0.1604)$ & -0.2841 & $(0.5508)$ & $0.3497 * *$ & $(0.1521)$ \\
\hline Efficiency $\left(\propto_{2}\right)$ & $1.3150^{* * *}$ & $(0.0369)$ & $6.9129 * * *$ & $(0.5565)$ & $2.3690 * * *$ & $(0.1680)$ \\
\hline Capital $\left(\propto_{3}\right)$ & $1.7379 * * *$ & $(0.0736)$ & $7.1976 * * *$ & $(1.8073)$ & $1.6620^{* * *}$ & $(0.3667)$ \\
\hline Size $\left(\propto_{4}\right)$ & $-0.0723^{* * *}$ & $(0.0112)$ & -0.0193 & $(0.0589)$ & $-0.0706 * * *$ & $(0.0140)$ \\
\hline GDP growth $\left(\propto_{5}\right)$ & $0.0364^{*}$ & $(0.0210)$ & $0.6539 * * *$ & $(0.1158)$ & 0.0387 & $(0.0271)$ \\
\hline Constant & $7.2328^{* * *}$ & $(0.2104)$ & $-11.6467 * * *$ & $(1.5494)$ & $6.1944^{* * *}$ & $(0.3310)$ \\
\hline \multicolumn{7}{|c|}{ Dependent variable is Capital (Eq. 7) } \\
\hline Earning assets Div. $\left(\beta_{1}\right)$ & $-0.2335^{* *}$ & $(0.0931)$ & 0.0406 & $(0.0714)$ & $-0.2102 *$ & $(0.1230)$ \\
\hline Efficiency $\left(\beta_{2}\right)$ & $-0.7567 * * *$ & $(0.0230)$ & $-0.9261 * * *$ & $(0.2751)$ & $-1.3939 * * *$ & $(0.4407)$ \\
\hline Risk $\left(\beta_{3}\right)$ & $0.5754 * * *$ & $(0.0245)$ & $0.1318^{* * *}$ & $(0.0448)$ & $0.5982 * * *$ & $(0.1917)$ \\
\hline Size $\left(\beta_{4}\right)$ & $0.0416^{* * *}$ & $(0.0069)$ & 0.0013 & $(0.0101)$ & $0.0421^{*}$ & $(0.0225)$ \\
\hline GDP growth $\left(\beta_{5}\right)$ & $-0.0210^{*}$ & $(0.0120)$ & $-0.0888 * * *$ & $(0.0159)$ & -0.0235 & $(0.0145)$ \\
\hline Constant & $-4.1618^{* * *}$ & $(0.2460)$ & $1.5809 * * *$ & $(0.2906)$ & $-3.7232 * *$ & $(1.4730)$ \\
\hline \multicolumn{7}{|c|}{ Dependent variable is Efficiency (Eq. 8) } \\
\hline Earning assets Div. $\left(\gamma_{1}\right)$ & $-0.3085^{* *}$ & $(0.1225)$ & 0.0415 & $(0.0788)$ & $-0.1476 * *$ & $(0.0661)$ \\
\hline Risk $\left(\gamma_{2}\right)$ & $0.7605^{* * *}$ & $(0.0214)$ & $0.1444^{* * *}$ & $(0.0115)$ & $0.4219 * * *$ & $(0.0329)$ \\
\hline Capital $\left(\gamma_{3}\right)$ & $-1.3216^{* * *}$ & $(0.0400)$ & $-1.0480 * * *$ & $(0.2304)$ & $-0.6989 * * *$ & $(0.1640)$ \\
\hline Size $\left(\gamma_{4}\right)$ & $0.0550 * * *$ & $(0.0088)$ & 0.0026 & $(0.0085)$ & $0.0299 * * *$ & $(0.0066)$ \\
\hline GDP growth $\left(\gamma_{5}\right)$ & $-0.0277^{*}$ & $(0.0159)$ & $-0.0948 * * *$ & $(0.0154)$ & -0.0162 & $(0.0116)$ \\
\hline Constant & $-5.5002 * * *$ & $(0.2544)$ & $1.6888^{* * *}$ & $(0.1771)$ & $-2.6139 * * *$ & $(0.3135)$ \\
\hline No. of observations & 360 & & 360 & & 360 & \\
\hline Chi-squared for Eq. 6 & 1380.4016 & & 204.7352 & & 350.6787 & \\
\hline Chi-squared for Eq. 7 & 1117.7582 & & 61.0045 & & 43.0690 & \\
\hline Chi-squared for Eq. 8 & 2494.2908 & & 207.7243 & & 167.4092 & \\
\hline
\end{tabular}

***, ** and *: $1 \%, 5 \%$ and $10 \%$ levels of significance, respectively

The results of Equation 8 indicate that revenue diversification $\left(\gamma_{1}\right)$ has an insignificant effect on cost efficiency, while earning assets diversification is significantly and negatively associated with cost efficiency as expected, supporting the "monitoring" hypothesis. The significant and positive parameter of Z-score $\left(\gamma_{2}\right)$ provides evidence of "bad luck" in 
Vietnamese banks. The significant and negative coefficient of capital ratio $\left(\gamma_{3}\right)$ indicates that banks with a lower capital ratio have a better cost efficiency score. One possible explanation is that low capital banks are forced to take strong action to improve cost efficiency in order to survive. The parameter of bank size $\left(\gamma_{4}\right)$ is positive, but is insignificant in Table 5 and significant in Table 6, suggesting that larger banks may have better cost efficiency scores, which could be explained by the advantage of economy of scale. Surprisingly, banks operating in a better economy have lower efficiency scores (a significant and negative parameter of GDP growth $\left(\gamma_{5}\right)$ ) . One possible explanation is that banks may be unable to keep costs under control when they considerably expand their assets in a better economy.

Table 7: Test for moral hazard hypothesis for the subsample of poorly capitalised banks when bank diversification is measured from the aspect of revenue

\begin{tabular}{|c|c|c|c|c|c|c|}
\hline \multirow{3}{*}{$\begin{array}{l}\text { Risk measurement } \\
\text { Efficiency estimation } \\
\text { technique } \\
\text { Column }\end{array}$} & \multirow{2}{*}{\multicolumn{2}{|c|}{$\begin{array}{c}\text { Risk = Z-score } \\
\begin{array}{c}\text { SFA Green (2005) } \\
\text { model }\end{array} \\
\end{array}$}} & \multirow{2}{*}{\multicolumn{2}{|c|}{$\begin{array}{c}\text { Risk = minus loan loss } \\
\text { provision ratio } \\
\text { SFA Green (2005) } \\
\text { model } \\
\end{array}$}} & \multicolumn{2}{|c|}{ Risk $=$ Z-score } \\
\hline & & & & & \multicolumn{2}{|c|}{$\begin{array}{c}\text { SFA Battese and } \\
\text { Coelli (1995) model }\end{array}$} \\
\hline & $\begin{array}{l}\text { Coef. } \\
(1)\end{array}$ & $\begin{array}{l}\text { Std. Err } \\
(2)\end{array}$ & $\begin{array}{l}\text { Coef. } \\
(3)\end{array}$ & $\begin{array}{l}\text { Std. Err } \\
(4)\end{array}$ & $\begin{array}{l}\text { Coef. } \\
(5)\end{array}$ & $\begin{array}{l}\text { Std. Err } \\
(6)\end{array}$ \\
\hline \multicolumn{7}{|c|}{ Dependent variable is Risk (Eq. 6) } \\
\hline Revenue Div. $\propto_{1}$ & 0.1053 & $(0.2313)$ & 0.0466 & $(0.8374)$ & $0.4738 * *$ & $(0.2047)$ \\
\hline Efficiency $\propto_{2}$ & $2.6374 * * *$ & $(0.6552)$ & $9.4896 * * *$ & (1.1683) & $4.4291 * * *$ & $(0.6158)$ \\
\hline Capital $\propto_{3}$ & $8.2328 * * *$ & $(2.0635)$ & $20.1367 * * *$ & $(4.1066)$ & $7.0226 * * *$ & $(1.1470)$ \\
\hline Size $\propto_{4}$ & $-0.0702 * * *$ & $(0.0137)$ & $-0.2224 * * *$ & $(0.0483)$ & $-0.0610 * * *$ & $(0.0112)$ \\
\hline GDP growth $\propto_{5}$ & 0.0358 & $(0.0310)$ & $0.1846^{*}$ & $(0.1096)$ & 0.0397 & $(0.0253)$ \\
\hline Constant & $5.8351 * * *$ & $(0.7637)$ & $-9.2737 * * *$ & $(1.6533)$ & $3.9412 * * *$ & $(0.6991)$ \\
\hline No of observations & \multicolumn{2}{|l|}{180} & \multicolumn{2}{|l|}{180} & \multicolumn{2}{|l|}{180} \\
\hline Chi-squared for Eq. 4 & \multicolumn{2}{|l|}{55.4061} & \multicolumn{2}{|l|}{98.7579} & \multicolumn{2}{|l|}{109.0259} \\
\hline
\end{tabular}

$* * *, * *$ and $*: 1 \%, 5 \%$ and $10 \%$ levels of significance, respectively

Table 8: Test for moral hazard hypothesis for the subsample of poorly capitalized banks when bank diversification is measured from the aspect of earning assets

\begin{tabular}{|c|c|c|c|c|c|c|}
\hline \multirow{3}{*}{$\begin{array}{l}\text { Risk measurement } \\
\text { Efficiency estimation } \\
\text { technique } \\
\text { Column }\end{array}$} & \multicolumn{2}{|c|}{ Risk $=$ Z-score } & \multirow{2}{*}{\multicolumn{2}{|c|}{$\begin{array}{c}\text { Risk }=\text { minus loan loss } \\
\text { provision ratio } \\
\text { SFA Green (2005) } \\
\text { model } \\
\end{array}$}} & \multicolumn{2}{|c|}{ Risk $=$ Z-score } \\
\hline & \multicolumn{2}{|c|}{$\begin{array}{c}\text { SFA Green (2005) } \\
\text { model }\end{array}$} & & & \multicolumn{2}{|c|}{$\begin{array}{c}\text { SFA Battese and } \\
\text { Coelli (1995) model }\end{array}$} \\
\hline & $\begin{array}{l}\text { Coef. } \\
(1)\end{array}$ & $\begin{array}{l}\text { Std. Err } \\
(2)\end{array}$ & $\begin{array}{l}\text { Coef. } \\
(3)\end{array}$ & $\begin{array}{c}\text { Std. Err } \\
(4)\end{array}$ & $\begin{array}{l}\text { Coef. } \\
(5)\end{array}$ & $\begin{array}{l}\text { Std. Err } \\
(6)\end{array}$ \\
\hline \multicolumn{7}{|c|}{ Dependent variable is Risk (Eq. 4) } \\
\hline Earning assets Div. $\left(\alpha_{1}\right)$ & $0.4451^{* *}$ & $(0.1887)$ & 0.8679 & $(0.5704)$ & $0.3354 * *$ & $(0.1518)$ \\
\hline Efficiency $\left(\alpha_{2}\right)$ & 0.7942 & $(0.9577)$ & $6.3465 * * *$ & $(1.0862)$ & $2.0918 * * *$ & $(0.4104)$ \\
\hline Capital $\left(\alpha_{3}\right)$ & 3.1288 & $(2.5279)$ & $11.9015^{* * *}$ & $(4.1287)$ & $4.0658 * * *$ & $(0.6920)$ \\
\hline Size $\left(\alpha_{4}\right)$ & $-0.0701 * * *$ & $(0.0119)$ & $-0.2203 * * *$ & $(0.0377)$ & $-0.0650 * * *$ & $(0.0098)$ \\
\hline
\end{tabular}




\begin{tabular}{lllllll} 
GDP growth $\left(\alpha_{5}\right)$ & 0.0280 & $(0.0261)$ & $0.1761^{* *}$ & $(0.0857)$ & 0.0351 & $(0.0222)$ \\
Constant & $7.6365^{* * *}$ & $(0.9414)$ & $-6.3409^{* * *}$ & $(1.4331)$ & $6.2937^{* * *}$ & $(0.4518)$ \\
No. of observations & 180 & & 180 & & 180 & \\
Chi-squared for Eq. 4 & 76.5637 & & 92.2640 & & 118.9062 \\
\hline
\end{tabular}

***, ** and *: $1 \%, 5 \%$ and $10 \%$ levels of significance, respectively

We also test "moral hazard" behaviour in the poorly capitalised banks by re-estimating the system of three equations (Equations 6 to 8) for the subsample of banks with the capital ratio below the sample median. The results for Equation 6 are displayed in Table 7 (bank diversification is measured from the aspect of revenue) and Table 8 (bank diversification is measured from the aspect of earning assets). It is apparent from the main model (i.e., using Zscore as a proxy for risk (the first two columns)) that a decrease in capital ratio in the sample of low capitalised banks $\left(\alpha_{3}\right)$ is significantly associated with a decrease in Z-score (i.e., a growth in insolvency risk) as in the sample of all banks, suggesting that "moral hazard" does exist in Vietnamese banks. In the sample of low capitalised banks, revenue diversification $\left(\alpha_{1}\right)$ has no significant effect on insolvency risk, but earning assets diversification has a negative impact, as it does in the sample of all banks.

\section{Robustness tests}

As mentioned previously, we test the robustness of the results using an alternative risk measurement (the loan loss provision ratio) and an alternative SFA model to estimate cost efficiency (the SFA model proposed by Battese and Coelli (1995)). The results of these models are presented in the last four columns of Tables 5 to 8 . Note that a greater Z-score indicates a lower risk level while a greater loan loss provision ratio shows a higher risk level. Therefore, for ease of comparison, we use the opposite of the loan loss provision ratio in the analysis.

In all robust tests, we mostly find consistent evidence of "classical diversification", "economic capital" and "monitoring" behaviours when bank diversification is captured from the aspect of earning assets, but no evidence supporting these behaviours when bank diversification is measured regarding revenue. As described in the data section, Vietnamese banks have diversified their revenue on a small level (non-interest revenue accounts for only $8.7 \%$ of total revenue), and hence a change in the proportion of non-interest revenue may be insufficient to have a significant effect on the efficiency, insolvency risk and capital ratio. However, Vietnamese banks have diversified their earning assets to a considerable degree (non-lending earning assets, on average, take up 39\% of total earning assets, with an 
increasing trend over the analysis period). The diversification lowers the dependence of Vietnamese banks on traditional lending activities, and hence diversification of earning assets lowers the risk of these banks. Moreover, total assets (denominator of the capital ratio) may have expanded due to the non-earning assets expansion, and total costs may have increased due to the professional employment and technology investment in order to manage nontraditional banking activities. This leads to the negative effects of diversification of earning assets on capital ratio and cost efficiency. Rossi et al. (2009) also support the "monitoring" and "classical diversification" behaviours on Austrian banks, but they did not conduct a comprehensive analysis such as the one in our study. Lee et al. (2014) also provided evidence of "classical diversification” behaviour in Asian banks, including Vietnam, when a proxy for earning assets diversification is applied, but no evidence to support or reject the "monitoring" behaviour when revenue diversification is applied.

We also find consistent evidence supporting "bad management", "bad luck" and "moral hazard" behaviours in all robustness tests, which is consistent with the findings of Deelchand and Padgett (2010) and Reddy (2011) on Japanese and Indian banks, respectively. The explanation is that the management of lower cost-efficient Vietnamese banks may also be worse at risk management (poor credit scoring, loan monitoring and investment analysing), while the management of banks operating in risky environments caused by external shocks, like economic downturns and financial crises, must put more managerial effort into monitoring delinquent borrowers, leading to lower cost efficiency. Moreover, the owners of poorly capitalised banks may be less active in monitoring the risk-taking activities of management, leading to an increase in risks.

\section{Conclusions}

To the best of the authors' knowledge, this is the first study identifying managerial behaviour in Vietnamese banks, based on the bank managerial framework developed by Rossi et al. (2009) (an extended framework of Berger and DeYoung (1997)), which is built on the interrelationships between cost efficiency, capital ratio and insolvency risk and the impact of revenue and earning assets diversification on these three variables. Another contribution of this study is that comprehensive tests for the sensitivity of the results have been conducted using an alternative risk measurement and an alternative efficiency SFA estimator. This study also utilises the most updated and comprehensive data set which consists of 32 local commercial banks over the period 2000 to 2014. 
This study uses the Z-score to measure the insolvency risk, the SFA model proposed by Greene (2005) to estimate cost efficiency, the ratio of total equity to total assets to capture capital, and the HHI index to measure diversification of revenue and earning assets. The result is that the cost efficiency of Vietnamese banks reveals an unclear trend over the period 2000 to 2014. Diversification of revenue has an insignificant impact on insolvency risk, capital ratio and cost efficiency, but diversification of earning assets has a negative effect on these three variables, supporting "classical diversification”, “economic capital” and “monitoring” behaviours. Moreover, a decline in cost efficiency leads to a rise in insolvency risk, implying "bad management” behaviour; an increase in risk results in a reduction in cost efficiency, indicating "bad luck" behaviour; and a reduction in capital ratio in poorly capitalised banks leads to a growth in risk, suggesting “moral hazard” behaviour. The results remain robust when using an alternative risk measurement (the ratio of loan loss provision to gross loans) and an alternative SFA model (the SFA model proposed by Battese and Coelli (1995)).

The findings of this study which characterise the managerial behaviours in Vietnamese banks have significant implications for policy makers and bank managers in initiating policies and strategies to improve bank efficiency and stability in Vietnam. In particular, increasing the diversification of earning assets and raising the capital ratio may lead to an improvement in the stability of Vietnamese banks. However, it is also noteworthy that there may be a tradeoff between stability and efficiency brought about by earning asset diversification and capitalisation. Furthermore, the findings on "bad management", "bad luck" and "moral hazard" behaviours suggest that monitoring more closely the operations of Vietnamese banks and the economic environment that these banks operate in, can help management keep costs under control and reduce risk-taking activities, i.e. mitigating "bad management”, "bad luck" and "moral hazard" behaviours. The reason is that if the banks can correctly forecast economic conditions, they can adjust their business strategies according to economic conditions in advance in order to avoid losses caused by economic downturns and financial crises. Moreover, under the pressure of monitoring, management may put more effort into keeping costs and risks under control. 


\section{References}

Aigner D, Lovell CAK, and Schmidt P. (1977). Formulation and estimation of stochastic frontier production function models. Journal of Econometrics, 6(1), 21-37.

Altunbas Y, Carbo S, Gardener EP, and Molyneux P. (2007). Examining the relationships between capital, risk and efficiency in European banking. European Financial Management, 13(1), 4970.

Altunbaş Y, and Chakravarty SP. (2001). Frontier cost functions and bank efficiency. Economics Letters, 72(2), 233-240.

Altunbaş Y, Gardener EPM, Molyneux P, and Moore B. (2001). Efficiency in european banking. European Economic Review, 45(10), 1931-1955.

Battese EG, Heshmati A, and Hjalmarsson L. (2000). Efficiency of labour use in the swedish banking industry: A stochastic frontier approach. [journal article]. Empirical Economics, 25(4), 623640.

Battese GE, and Coelli TJ. (1995). A model for technical inefficiency effects in a stochastic frontier production function for panel data. Empirical Economics, 20(2), 325-332.

Beck T, De Jonghe O, and Schepens G. (2013). Bank competition and stability: Cross-country heterogeneity. Journal of Financial Intermediation, 22(2), 218-244.

Berger AN, and DeYoung R. (1997). Problem loans and cost efficiency in commercial banks. Journal of Banking \& Finance, 21(6), 849-870.

Berger AN, Hasan I, and Zhou M. (2010). The effects of focus versus diversification on bank performance: Evidence from Chinese banks. Journal of Banking \& Finance, 34(7), 14171435.

Berger AN, and Humphrey DB. (1997). Efficiency of financial institutions: International survey and directions for future research. European journal of operational research, 98(2), 175-212.

Bond SR. (2002). Dynamic panel data models: A guide to micro data methods and practice. Portuguese economic journal, 1(2), 141-162.

Chaponnière J-R, Cling J-P, and Zhou B. (2007). Vietnam following in china's footsteps: The third wave of emerging Asian economies. Paper presented at the WIDER Conference on Southern Engines of Global Growth: China, India, Brazil and South Africa, Helsinki, 7-8 September 2007.

Charnes A, Cooper WW, and Rhodes E. (1978). Measuring the efficiency of decision-making units. European Journal of Operational Research, 2(6), 429-444.

Chiorazzo V, Milani C, and Salvini F. (2008). Income diversification and bank performance: Evidence from italian banks. Journal of Financial Services Research, 33(3), 181-203.

Deelchand T, and Padgett C. (2010). The relationship between risk, capital and efficiency: Evidence from Japanese cooperative banks. ICMA Centre Discussion Papers in Finance DP2009-12. University of Reading.

Demirgüç-Kunt A, and Huizinga H. (2010). Bank activity and funding strategies: The impact on risk and returns. Journal of Financial Economics, 98(3), 626-650. 
Elsas R, Hackethal A, and Holzhäuser M. (2010). The anatomy of bank diversification. Journal of Banking \& Finance, 34(6), 1274-1287.

Elyasiani E, and Wang Y. (2012). Bank holding company diversification and production efficiency. Applied Financial Economics, 22(17), 1409-1428.

Fiordelisi F, Marques-Ibanez D, and Molyneux P. (2011). Efficiency and risk in European banking. Journal of Banking \& Finance, 35(5), 1315-1326.

Gardener E, Molyneux P, and Nguyen-Linh H. (2011). Determinants of efficiency in Southeast Asian banking. The Service Industries Journal, 31(16), 2693-2719.

Goddard J, McKillop D, and Wilson JO. (2008). The diversification and financial performance of us credit unions. Journal of Banking \& Finance, 32(9), 1836-1849.

Greene W. (2005). Fixed and random effects in stochastic frontier models. Journal of Productivity Analysis, 23(1), 7-32.

Hayden E, Porath D, and Westernhagen Nv. (2007). Does diversification improve the performance of German banks? Evidence from individual bank loan portfolios. Journal of Financial Services Research, 32(3), 123-140.

Houston JF, Lin C, Lin P, and Ma Y. (2010). Creditor rights, information sharing, and bank risk taking. Journal of Financial Economics, 96(3), 485-512.

Kwan S, and Eisenbeis RA. (1997). Bank risk, capitalization, and operating efficiency. Journal of Financial Services Research, 12(2-3), 117-131.

Laeven L, and Levine R. (2009). Bank governance, regulation and risk taking. Journal of Financial Economics, 93(2), 259-275.

Lee C-C, Yang S-J, and Chang C-H. (2014). Non-interest income, profitability, and risk in banking industry: A cross-country analysis. The North American Journal of Economics and Finance, 27, 48-67.

Lepetit L, Nys E, Rous P, and Tarazi A. (2008). Bank income structure and risk: An empirical analysis of European banks. Journal of banking \& finance, 32(8), 1452-1467.

Meeusen W, and Van den Broeck J. (1977). Efficiency estimation from Cobb-Douglas production functions with composed error. International Economic Review, 18(2), 435-444.

Mercieca S, Schaeck K, and Wolfe S. (2007). Small European banks: Benefits from diversification? Journal of Banking \& Finance, 31(7), 1975-1998.

Meslier C, Tacneng R, and Tarazi A. (2014). Is bank income diversification beneficial? Evidence from an emerging economy. Journal of International Financial Markets, Institutions and Money, 31(1), 97-126.

Nguyen TPT, Nghiem SH, Roca E, and Sharma P. (2016). Efficiency, innovation and competition: Evidence from Vietnam, China and India. Empirical Economics, 1-25.

Nguyen TPT, Roca E, and Sharma P. (2014). How efficient is the banking system of Asia's next economic dragon? Evidence from rolling DEA windows. Applied Economics, 46(22), 1-20.

Pomfret R. (2013). Asean's new frontiers: Integrating the newest members into the ASEAN economic community. Asian Economic Policy Review, 8(1), 25-41. 
Reddy KS. (2011). Management behaviour in Indian commercial banks. International Review of Accounting, Banking and Finance, 3(3), 4170-4192.

Rhoades SA. (1993). The Herfindahl-Hirschman Index. Federal Reserve Bulletin, 79, 188-189.

Rossi SP, Schwaiger MS, and Winkler G. (2009). How loan portfolio diversification affects risk, efficiency and capitalization: A managerial behavior model for Austrian banks. Journal of banking \& finance, 33(12), 2218-2226.

Roy AD. (1952). Safety first and the holding of assets. Econometrica: Journal of the Econometric Society, 20(3), 431-449.

Sanya S, and Wolfe S. (2011). Can banks in emerging economies benefit from revenue diversification? Journal of Financial Services Research, 40(1-2), 79-101.

Sealey CW, and Lindley JT. (1977). Inputs, outputs, and a theory of production and cost at depository financial institutions. The Journal of Finance, 32(4), 1251-1266.

Stiroh KJ. (2004). Diversification in banking: Is noninterest income the answer? Journal of Money, Credit and Banking, 853-882.

Tan Y, and Floros C. (2013). Risk, capital and efficiency in Chinese banking. Journal of International Financial Markets, Institutions and Money, 26, 378-393.

Vu H, and Nahm D. (2013). The determinants of profit efficiency of banks in Vietnam. Journal ofthe Asia Pacific Economy, 18(4), 615-631.

Vu H, and Turnell S. (2010). Cost efficiency of the banking sector in Vietnam: A bayesian stochastic frontier approach with regularity constraints. Asian Economic Journal, 24(2), 115-139.

Williams J. (2004). Determining management behaviour in European banking. Journal of Banking \& Finance, 28(10), 2427-2460.

WorldBank. (2002). Banking sector review: Vietnam - June 2002. The World Bank Financial Sector East Asia and Pacific Region.

Zellner A, and Theil H. (1962). Three-stage least squares: Simultaneous estimation of simultaneous equations. Econometrica: Journal of the Econometric Society, 54-78. 